\title{
Effects of Iron-Unsaturated Human Lactoferrin on Hydrogen Peroxide-Induced Oxidative Damage in Intestinal Epithelial Cells
}

\author{
HIROMICHI SHOJI, SATOSHI OGUCHI, KOICHI SHINOHARA, TOSHIAKI SHIMIZU, AND YUICHIRO YAMASHIRO \\ Department of Pediatrics and Adolescent Medicine, Juntendo University School of Medicine, 113-0033 Tokyo, Japan
}

\begin{abstract}
Human milk (HM) contains various bioactive antioxidants. Lactoferrin (Lf) has been assumed to be one of the major antioxidants in HM. We examined the antioxidative properties of iron-unsaturated human Lf (apo-hLf, the major form of Lf in HM) in two intestinal epithelial cell lines: (1) An intestinal epithelial cell line (IEC-6) were preincubated for $24 \mathrm{~h}$ with either $50 \mu \mathrm{g} / \mathrm{mL}$ of apo-hLf, iron-saturated human Lf (holo-hLf), iron-unsaturated bovine transferrin (apo-bTf), or $800 \mathrm{ng} / \mathrm{mL}$ of the iron-chelating compound deferoxamine (DFX), followed by hydrogen peroxide $\left(\mathrm{H}_{2} \mathrm{O}_{2}\right)$ challenge to induce oxidative stress. Survival rates were significantly higher in the cells preincubated with apo-hLf and DFX than those preincubated with holo-hLf. (2) Caco-2 cells were preincubated with or without apo-hLf for $24 \mathrm{~h}$, followed by an $\mathrm{H}_{2} \mathrm{O}_{2}$ challenge. Intracellular oxidative stress was assessed by a fluorescent probe, $2^{\prime}, 7^{\prime}$-dichlorodihydrofluorescein diacetate (DCF-DA). Fluorescent intensity of cell images and cell homogenates was significantly lower in the cells preincubated with apo-hLF than those preincubated without apo-hLF. Our study indicates that apo-hLf alleviates $\mathrm{H}_{2} \mathrm{O}_{2}$ induced oxidative damage in intestinal cells due to the iron-chelating capacity. Therefore, Lf in HM may act as an antioxidant in the gastrointestinal tract (GIT). (Pediatr Res 61: 89-92, 2007)
\end{abstract}

$\mathrm{O}$ xidative stress occurs when there is an imbalance between the amount of antioxidant properties and reactive oxygen species. In the neonatal period, especially in preterm infants injury to the GIT by oxidative stress is thought to be involved in the pathogenesis of serious diseases such as necrotizing enterocolitis $(1,2)$.

$\mathrm{HM}$ is the ideal food during infancy and is known to contain various types of bioactive substances, some of which are reported to be antioxidants (3). We demonstrated the antioxidative effects of HM in two previous studies. The level of urinary 8-hydroxy-2'-deoxyguanosine (a marker of oxidative DNA damage) excretions of breast-fed infants was significantly lower than that of formula-fed infants in 1 mo of age (4). HM-treated IEC-6 cells showed a significantly higher survival rate after $\mathrm{H}_{2} \mathrm{O}_{2}$-induced oxidative damage than cells treated with infant formula (5). Despite these findings, it is

Received April 26, 2006; accepted August 18, 2006.

Correspondence: Hiromichi Shoji, M.D., Department of Pediatrics Juntendo University, School of Medicine 2-1-1 Hongo, Bunkyo-ku, 113-0033 Tokyo, Japan; e-mail: hiromichi.shoji@nifty.ne.jp

DOI: 10.1203/01.pdr.0000250198.22735.20 still unclear which components of HM play the most important antioxidative roles in the GIT of infants.

Lf is an iron-binding glycoprotein that belongs to the transferrin (Tf) family. Although it has been identified in many secretions from various species, it mainly exists in mammalian milk and colostrum. The amino acid compositions of bovine Lf and human Lf show 69\% sequence homology (6). Lf appears to play a role in many biologic processes, including the proliferation and differentiation of enterocytes (7), regulation of iron absorption (8), antimicrobial activities (9), immunomodulation and anti-inflammatory responses (10), and antivirus or anticancer activities (11). Lf is considered to be an antioxidant because of its ability to bind two atoms of iron, which is important in the formation of free radicals (12). Interestingly, Lf concentration and iron saturation in milk vary considerably with species; bovine milk contains approximately $0.1 \mathrm{mg} / \mathrm{mL}$ of $\mathrm{Lf}$ that is $22 \%$ saturated with iron compared with an average $\mathrm{Lf}$ of $1.4 \mathrm{mg} / \mathrm{mL}$ (10\%-20\% of the total protein) in mature HM that is only $4 \%$ iron saturated (13).

Recently, a fluorescent probe is one of the most straightforward techniques used in the assessment of intracellular oxidative stress. The fluorescent reporter molecule DCFH-DA is a commonly used intracellular fluorescent probe that diffuses rapidly through cell membranes and is subsequently hydrolyzed to DCFH by intracellular esterases. The nonfluorescent DCFH subsequently trapped inside the cell, whereupon oxidation changes it to the highly fluorescent dichlorofluorescein (DCF). It may serve as a sensitive cytosolic marker of oxidative stress. It has been proposed that DCFH detects a broad range of oxidation reactions that occur during intracellular oxidative stress (14).

In the present study, we attempt to determine the antioxidative capacities of apo-hLf in comparison with those of holo-hLf, apo-bTf, and the iron chelator DFX in an IEC to clarify whether apo-hLf exhibits its iron-chelating capacity to reduce oxidative stress. Furthermore, we used DCFH-DA to demonstrate the cell protection mechanisms of apo-hLf during $\mathrm{H}_{2} \mathrm{O}_{2}$-induced oxidative damage.

\footnotetext{
Abbreviations: apo-bTf, iron unsaturated bovine transferrin; apo-hLf, ironunsaturated human lactoferrin; CLSM, confocal laser scanning microscope; DCF, dichlorofluorescein; DCFH-DA, 2' 7' $^{\prime}$-dichlorodihydrofluorescein diacetate; DFX, deferoxamine; GIT, gastrointestinal tract; $\mathbf{H}_{2} \mathbf{O}_{2}$, hydrogen peroxide; HM, human milk; holo-hLf, iron-saturated human; Lf, lactoferrin; NR, neutral red; Tf, transferrin
} 


\section{METHODS}

Cell lines. For cell viability experiments, we used IEC-6 cells (ATCC, Rockville, MD, obtained from the Riken Cell Bank, Ibaraki, Japan, passages between 15 and 25 after acquisition) derived from a nontransformed rat intestinal crypt cell. The cells were maintained in Dulbecco's modified Eagle's medium (DMEM) (GIBCO Laboratories, Grand Island, NY) containing $5 \%$ fetal calf serum (FCS) (GIBCO), $4.5 \mathrm{~g} / \mathrm{L}$ glucose, $0.1 \mathrm{U} / \mathrm{mL}$ insulin (Wako Pure Chemical Industries, Osaka, Japan), $5 \mathrm{mmol} / \mathrm{L}$ L-glutamine (GIBCO), $100 \mathrm{U} / \mathrm{mL}$ penicillin, and $100 \mu \mathrm{g} / \mathrm{mL}$ streptomycin (GIBCO).

For fluorescent intensity experiments, we used Caco-2 cells (ATCC, obtained from the official distributor in Japan, passages between 40 and 50) derived from a human colon adenocarcinoma. These cells spontaneously differentiated in culture resemble small intestinal enterocytes in both morphology and biochemical function. The cells were maintained in stock cultures in DMEM supplemented with $2 \mathrm{mmol} / \mathrm{L}$ glutamine, $10 \%$ FCS, 0.1 $\mathrm{mmol} / \mathrm{L}$ nonessential amino acids, $100 \mathrm{U} / \mathrm{mL}$ penicillin, and $100 \mu \mathrm{g} / \mathrm{mL}$ streptomycin (GIBCO). Cells were cultured in a humidified incubator with an atmosphere of $5 \% \mathrm{CO}_{2}$ at $37^{\circ} \mathrm{C}$ and were supplied fresh medium every $2 \mathrm{~d}$.

Oxidative stress and cell viability evaluation. $\mathrm{H}_{2} \mathrm{O}_{2}$ (Wako) was added to the culture medium to induce oxidative stress. Neutral red (NR), which is only taken up by living cells, was used to measure cell survival rates (15). Cells were incubated with $0.33 \mathrm{~g} / \mathrm{L}$ NR (Sigma Chemical Co. St. Louis, MO) in DMEM for $1 \mathrm{~h}$. Subsequently, the cell layer was rinsed twice with phosphatebuffered saline (PBS) (GIBCO), and NR was extracted with $1 \%$ (vol/vol) acetic acid in a 1:1 water:ethanol mixture. Absorbance at $560 \mathrm{~nm}$ was measured spectrophotometrically.

Preliminary experiments. Two preliminary experiments were performed to determine suitable experimental conditions.

$\mathrm{H}_{2} \mathrm{O}_{2}$ concentration. To determine the optimal concentration of $\mathrm{H}_{2} \mathrm{O}_{2}$ for the oxidative challenge, confluent IEC- 6 cells that were preincubated with or without $50 \mu \mathrm{g} / \mathrm{mL}$ apo-hLf (Sigma Chemical Co.) for $24 \mathrm{~h}$ were subsequently treated with $0.1,0.25$, or $0.5 \mathrm{mmol} / \mathrm{L} \mathrm{H}_{2} \mathrm{O}_{2}$ for $30 \mathrm{~min}$ at $37^{\circ} \mathrm{C}$.

apo-hLf concentration. To define the most effective concentration of apo-hLf, confluent IEC- 6 cells were examined for $24 \mathrm{~h}$ with $0,5,25$, or 50 $\mu \mathrm{g} / \mathrm{mL}$ apo-hLf at $37^{\circ} \mathrm{C}$ and then challenged with $0.25 \mathrm{mmol} / \mathrm{L} \mathrm{H}_{2} \mathrm{O}_{2}$ for 30 $\min$ at $37^{\circ} \mathrm{C}$.

Cell viability experiment. IEC-6 cells were cultivated with FCS-containing medium in a 48-well culture plate (Coster Corp., Cambridge, MA) at an initial cell density of $5 \times 10^{4} / \mathrm{cm}^{2}$. On d 5 , the medium was replaced by medium without FCS and cells were preincubated for $24 \mathrm{~h}$ either with $50 \mu \mathrm{g} / \mathrm{mL}$ of apo-hLf, holo-hLf (Sigma Chemical Co.), apo-bTf (Sigma Chemical Co.), or $800 \mathrm{ng} / \mathrm{mL}$ DFX (Sigma Chemical Co.) in minimal essential medium (MEM) (GIBCO), which does not contain iron, to minimize the effect of free iron ion. On d $6, \mathrm{H}_{2} \mathrm{O}_{2}$ (final concentration of $0.25 \mathrm{mmol} / \mathrm{L}$ ) was applied as a challenge for $30 \mathrm{~min}$. Cells were washed three times with PBS and then incubated for $24 \mathrm{~h}$ with complete medium. On d 7, an NR uptake assay was performed.

Fluorescence intensity experiment. Caco-2 cells at an initial cell density of $5 \times 10^{4} / \mathrm{cm}^{2}$ were grown in $35-\mathrm{mm}$ glass bottom culture dishes with FCS-containing medium. After differentiated cells were confluent (d 21), Caco-2 cells were preincubated for $24 \mathrm{~h}$ in MEM (without FCS) with or without the addition of $50 \mu \mathrm{g} / \mathrm{mL}$ of apo-hLF. Then cells were treated with 1 $\mathrm{mmol} / \mathrm{L} \mathrm{H}_{2} \mathrm{O}_{2}$ in MEM for $45 \mathrm{~min}$, followed by incubation with $10 \mu \mathrm{mol} / \mathrm{L}$ DCFH-DA at $37^{\circ} \mathrm{C}$ in a dark environment for $10 \mathrm{~min}$, and washed with PBS three times.

Fluorescent intensity of images. The images of Caco-2 cells exhibiting DCF fluorescence were taken using a confocal laser scanning microscope (CLSM) (Nikon). The images of five different, randomly selected fields (60-80 min after the DCFH-DA treatment), were stored in a personal computer. Quantitative analysis of fluorescent intensity was performed using NIH Image (version 1.61)

Fluorescent intensity of cell homogenates. After DCFH-DA treatment, the cells were removed from the culture dishes by scraping and placed on ice. Using a Potter-type homogenizer, the cells were disrupted in ice-cold phosphate buffer containing $0.1 \%$ (vol/vol) Triton X-100. The homogenate was centrifuged at $15,000 \times g$ for $15 \mathrm{~min}$ at $4^{\circ} \mathrm{C}$. Fluorescent intensities were quantified with a fluorometer. Total protein concentrations of cell homogenates were determined using a Bio-Rad protein assay with bovine serum albumin as the standard. Results were expressed as a ratio of fluorescence intensity per milligram of total protein.

Data analysis. All data were expressed as the mean \pm standard deviation (SD). Differences between groups were analyzed with a $t$ test. Differences from baseline were tested by one-way analysis of variance and, if indicated, by post hoc Tukey-Kramer test. A $p$ value $<0.05$ was considered statistically significant. All statistical analyses were performed with StatView 5.0 (Abacus Concepts, Inc., Berkeley, CA).

\section{RESULTS}

Optimal concentration of $\mathrm{H}_{2} \mathrm{O}_{2}$. Cell viability decreased as the concentration of $\mathrm{H}_{2} \mathrm{O}_{2}$ increased. Survival rates of IEC-6 cells preincubated with $50 \mu \mathrm{g} / \mathrm{mL}$ of apo-hLf after the $0-, 0.1-$, 0.25 -, or $0.5-\mathrm{mmol} / \mathrm{L} \mathrm{H}_{2} \mathrm{O}_{2}$ challenge were $102.6 \pm 8.1 \%$, $97.9 \pm 4.6 \%, 92.0 \pm 2.0 \%$, and $49.2 \pm 3.1 \%$, respectively ( $n=6$, mean $\pm \mathrm{SD})$. In contrast, survival rates of the cells after the $\mathrm{H}_{2} \mathrm{O}_{2}$ challenge without apo-hLf preincubation were $100.1 \pm 5.4 \%, 98.1 \pm 3.6 \%, 77.2 \pm 5.3 \%$, and $24.4 \pm 3.8 \%$, respectively ( $n=6$, mean \pm SD) (Fig. 1$)$. After the 0.25 - and $0.5-\mathrm{mmol} / \mathrm{L} \quad \mathrm{H}_{2} \mathrm{O}_{2}$ challenge, significantly higher survival rates were observed in the cells preincubated with apo-hLf than those preincubated without apo-hLf. Therefore, 0.25 $\mathrm{mmol} / \mathrm{L} \mathrm{H}_{2} \mathrm{O}_{2}$ was considered to be optimal.

Optimal concentration of apo-hLf for preincubation. Increasing concentrations of apo-hLf were added and preincubated for $24 \mathrm{~h}$ before the $0.25-\mathrm{mmol} / \mathrm{L} \mathrm{H}_{2} \mathrm{O}_{2}$ challenge. The survival rates of no pretreatment cells $\left(\mathrm{H}_{2} \mathrm{O}_{2}\right.$ challenge only) or the cells preincubated with 5,25 , and $50 \mu \mathrm{g} / \mathrm{mL}$ apo-hLf were $69.5 \pm 1.7 \%, 70.8 \pm 1.7 \%, 78.5 \pm 5.2 \%$, and $82.1 \pm$ $7.3 \%$, respectively ( $n=6$, mean \pm SD) (Fig. 2). Cell viabilities of the cells preincubated with 25 and $50 \mu \mathrm{g} / \mathrm{mL}$ apo-hLf were significantly higher than those of untreated cells. Therefore, the concentration of $50 \mu \mathrm{g} / \mathrm{mL}$ was chosen.

Cell viability experiment. The cell survival rates of untreated IEC-6 cells and the rates for cells preincubated with apo-hLf, holo-hLf, apo-bTf, or DFX were $76.8 \pm 2.5 \%, 95.7 \pm 5.8 \%$, $80.5 \pm 4.4 \%, 88.0 \pm 1.7 \%, 99.7 \pm 5.1 \%$, respectively $(n=6$, mean \pm SD) (Fig. 3). Survival rates of the cells preincubated with apo-hLf, apo-bTf, or DFX were significantly higher than those of untreated cells or cells preincubated with holo-hLf. Survival rates of the cells preincubated with apo-bTf were also significantly higher than those of untreated cells.

Fluorescence intensities of images. Fluorescence of DCF was most evident along the cell membrane (Fig. 4a). In the CLSM images, the fluorescent intensities of Caco- 2 cells preincubated with apo-hLF were lower compared with those of untreated cells. Fluorescent intensities, as measured by NIH

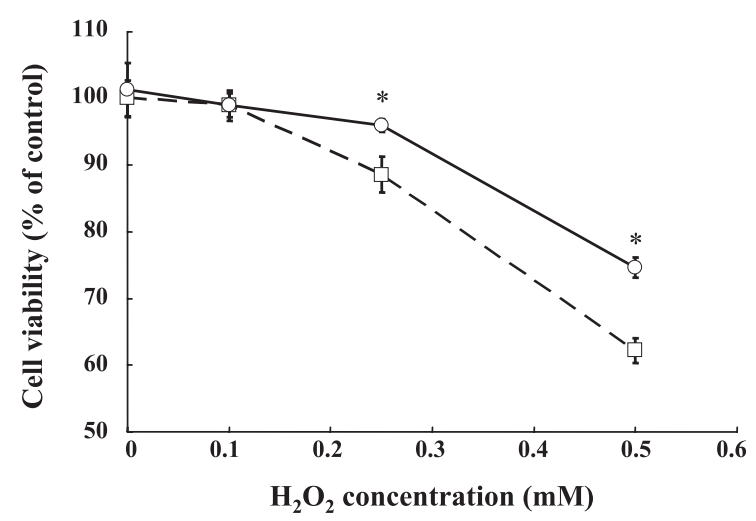

Figure 1. Effect of apo-hLf on $\mathrm{H}_{2} \mathrm{O}_{2}$-induced oxidative damage in IEC-6 cells. Confluent IEC-6 cells were preincubated with (solid line) or without (dashed line) $50 \mu \mathrm{g} / \mathrm{mL}$ of apo-hLf followed by increasing concentrations of $\mathrm{H}_{2} \mathrm{O}_{2}$ challenge for $30 \mathrm{~min}$ at $37^{\circ} \mathrm{C}$. Surviving cell rates are expressed as a percentage of control $\left(0 \mathrm{mmol} / \mathrm{L} \mathrm{H}_{2} \mathrm{O}_{2}\right)$. Data represent the means $\pm \mathrm{SD}$ of six replicate wells for a single experiment that is representative of three comparable experiments. ${ }^{*} p<0.05$ compared with value of no apo-hLf group. 


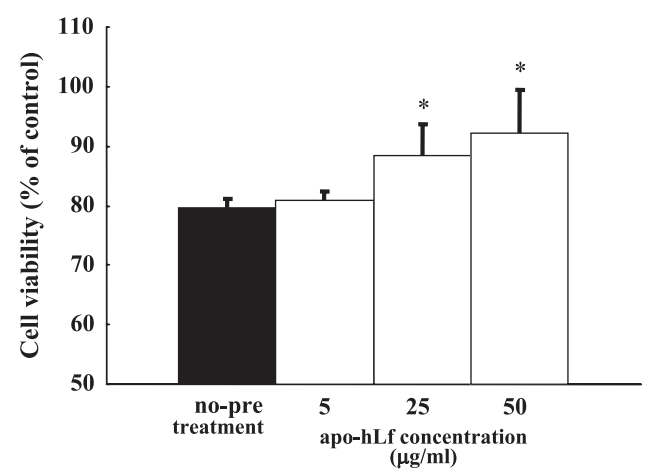

Figure 2. Effect of pretreatment with apo-hLf on $\mathrm{H}_{2} \mathrm{O}_{2}$-induced oxidative damage in IEC-6 cells. Confluent IEC-6 cells were preincubated for $24 \mathrm{~h}$ with different concentrations of apo-hLf at $37^{\circ} \mathrm{C}$ and then challenged $\mathrm{H}_{2} \mathrm{O}_{2}(0.25$ $\mathrm{mmol} / \mathrm{L}, 30 \mathrm{~min}$ ). No pretreatment samples received only $\mathrm{H}_{2} \mathrm{O}_{2}$. Surviving cell rates are expressed as a percentage of control (no $\mathrm{H}_{2} \mathrm{O}_{2}$ challenge) cells. Data represent the means \pm SD of six replicate wells for a single experiment that is representative of three comparable experiments. The data were analyzed by one-way analysis of variance with post hoc analysis by the TukeyKramer test. ${ }^{*} p<0.05$ compared with value of no pretreatment group.

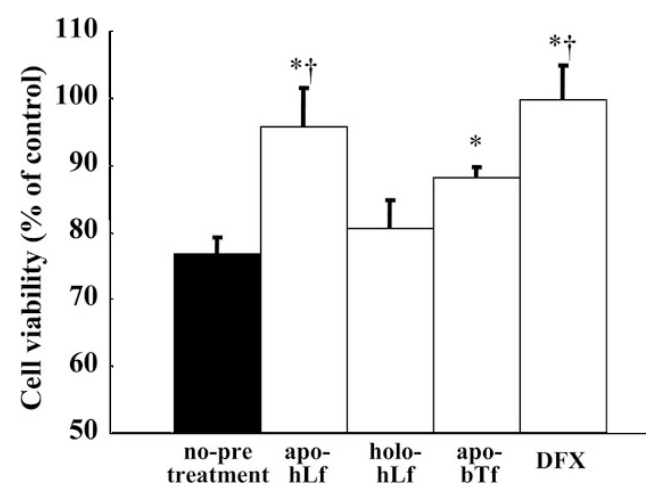

Figure 3. Antioxidative property of apo-hLf, holo-hLf, apo-bTf, and DFX on $\mathrm{H}_{2} \mathrm{O}_{2}$-induced oxidative damage in IEC-6 cells. Confluent cells were preincubated with $50 \mu \mathrm{g} / \mathrm{mL}$ of apo-hLf, holo-hLf, or apo-bTf or $800 \mathrm{ng} / \mathrm{mL}$ of DFX for $24 \mathrm{~h}$ at $37^{\circ} \mathrm{C}$. Then $0.25 \mathrm{mmol} / \mathrm{L} \mathrm{H}_{2} \mathrm{O}_{2}$ was applied as a challenge for $30 \mathrm{~min}$. Survived cell rate are expressed as a percentage of control (no $\mathrm{H}_{2} \mathrm{O}_{2}$ challenge) cells. Data represent the means \pm SD of six replicate wells for a single experiment that is representative of three comparable experiments. The data were analyzed by one-way analysis of variance with post hoc analysis by the Tukey-Kramer test. ${ }^{*} p<0.05$ compared with value of no pretreatment group. $\dagger p<0.05$ compared with value of the holo-hLf group.

Image analysis software, were significantly lower in the cells preincubated with apo-hLF than in untreated cells $(33.4 \pm 3.5$ and $47.0 \pm 10.0$ relative intensity unit, respectively; $n=5$, mean \pm SD) (Fig. 4b).

Fluorescent intensities of cell homogenates. Fluorescent intensities of cell homogenates (expressed as protein ratio) were significantly lower in the cells preincubated with apo$\mathrm{hLf}$ than in untreated cells $(13.3 \pm 3.2$ and $15.4 \pm 3.6$ relative light unit/milligram of protein, respectively; $n=6$, mean \pm SD) (Fig. 4c).

\section{DISCUSSION}

We evaluated the antioxidative effects of apo-hLf in intestinal epithelial cell lines. Significantly higher survival rates were observed in the cells preincubated with the iron-unsaturated form of iron binding proteins and/or an iron-chelating agent.
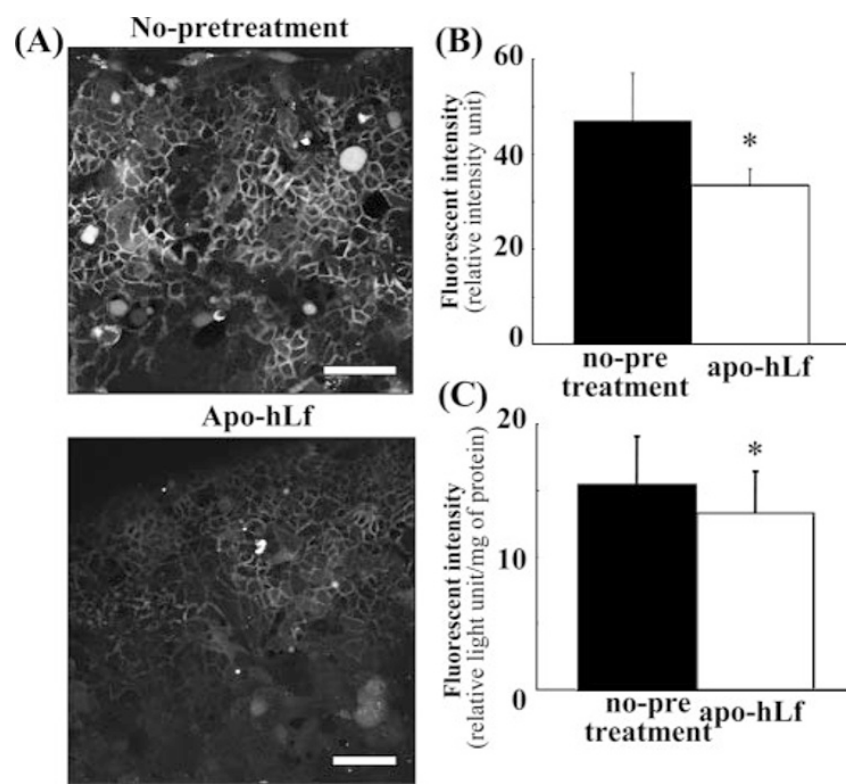

Figure 4. Effect of apo-hLf on $\mathrm{H}_{2} \mathrm{O}_{2}$ in DCF fluorescence in Caco-2 cells. Cells were preincubated with or without $50 \mu \mathrm{g} / \mathrm{mL}$ of apo-hLF for $24 \mathrm{~h}$. Cells were treated with $1 \mathrm{mmol} / \mathrm{L} \mathrm{H}_{2} \mathrm{O}_{2}$ in culture medium for $45 \mathrm{~min}$, followed by incubation with $10 \mu \mathrm{mol} / \mathrm{L}$ DCFH-DA at $37^{\circ} \mathrm{C}\left(5 \% \mathrm{CO}_{2}\right.$-air:atmosphere) for 10 min. Fluorescent DCF images were taken using a CLSM. (a) Representative DCF fluorescent images from no preincubated cells $(56 \mathrm{~min}$ after DCFH-DA treatment) and preincubated with apo-hLf cells (55 $\mathrm{min}$ after DCFH-DA treatment). Scale bars $=20 \mu \mathrm{m}$. (b) Fluorescent intensity of CLSM images. The images of five different, randomly selected fields were stored in a personal computer. Quantitative analysis of fluorescent intensity was performed using NIH Image, expressed as relative intensity unit. (c) Fluorescent intensity of cell homogenates. After DCFH-DA treatment, the cells were removed from the culture dishes by scraping and were disrupted in ice-cold phosphate buffer containing $0.1 \%$ (vol/vol) Triton X-100 using a homogenizer. Fluorescent intensities were quantified with a fluorometer. Results were expressed as a ratio of fluorescence intensity per milligram of total protein (relative light unit/milligram of protein). Values are means $+\mathrm{SD}$ $(n=6)$. The data were analyzed by $t$ test. *Statistically different $(p<0.05)$.

Lf binds two atoms of ferric iron with high affinity (300 times higher than $\mathrm{Tf}$ ) and still maintains function as an iron chelator. Huang et al. (16) reported that iron-unsaturated Lf has an antioxidant effect on a corn oil emulsion and on a lecithin liposome system, although iron-saturated Lf was unable to inhibit oxidation in a liposome system. Furthermore, iron-unsaturated Lf decreased the generation of hydroxyl radical by phagocytes and inhibited iron-catalyzed auto-oxidation of monocyte membranes (17).

Lf-specific receptors have been identified in brush-border membranes of fetal and infant intestines (18) and have been suggested to contribute to the cellular iron uptake. $\mathrm{Lf}$ receptor is also identified in IEC-6 cells (19) and Caco-2 cells (20). Ashida et al. (21) also reported that human Lf was internalized by Caco-2 cells from the apical side and localized to the nuclei. These studies showed that Caco- 2 and IEC- 6 cell lines are useful models to assess the effect of Lf in the intestine.

The results of fluorescence experiments indicate that oxidative stress levels of apo-hLf treated cells were significantly lower than those of untreated cells. Previous studies implicated a role for redox-active iron in cellular oxidation of DCFH to DCF $(22,23)$. In contrast, $\mathrm{H}_{2} \mathrm{O}_{2}$-induced intracellular 
DCF fluorescence was inhibited by iron chelators (24). We speculate that apo-hLf in culture medium chelates intra- and extracellular free ferric iron, which subsequently decreases intracellular free ferrous iron and results in decreased oxidative stress. However, we have no evidence of whether Lf receptors in intestinal cells can uptake both holo and apo forms of Lf. Additional studies are needed, but previous studies reported the recognition of Lf by the Lf receptor of the protozoan parasite Leishmania donovani being independent of whether it is metal loaded (25). Conversely, the affinity of metal-loaded $\mathrm{Tf}$ for the $\mathrm{Tf}$ receptor is much higher than that of apo-Tf (26). Zhang et al. also demonstrated that apo-hLf can be recognized as well as holo-hLf in IEC-6 cells (19).

Supplementation of iron in infant formula or breast milk has the potential of exacerbating free radical oxidation via its role as a catalyst in oxidative stress (27). However, the use of iron-fortified infant formulas also prevents iron deficiency anemia among full-term infants (28). Lf is known to be partially resistant to proteolysis by addition of trypsin (29), and it has been shown that a significant proportion of $\mathrm{Lf}$ can survive digestion in infants (30). Bovine Lf has been added to infant formula since 1986, but clinical trials have not shown any enhancing effect on iron absorption or iron status $(31,32)$ because the binding of hLf receptor is considered specific for hLF (33). Suzuki and colleagues (34) recently demonstrated that recombinant hLf expressed in rice shows stable biologic activities similar to those of native hLf. This suggests that recombinant hLf may be a valuable source when added to infant formula.

The present findings indicate that apo-hLf and other ironbinding compounds alleviate $\mathrm{H}_{2} \mathrm{O}_{2}$-induced oxidative damage in IEC-6 cells and apo-hLf cells. Pretreatment of Caco-2 cells with apo-Lf appears to attenuate the intracellular oxidative stress caused by exogenous $\mathrm{H}_{2} \mathrm{O}_{2}$. We speculate that the iron-chelating capacity of apo-Lf plays an important role in reducing oxidative stress in these systems. In conclusion, our findings suggest that iron-unsaturated Lf in human breast milk acts as an antioxidant in the GIT.

\section{REFERENCES}

1. Clark DA, Fornabaio DM, McNeill H, Mullane KM, Caravella SJ, Miller MJ 1988 Contribution of oxygen-derived free radicals to experimental necrotizing enterocolitis. Am J Pathol 130:537-542

2. Okur H, Kucukaydin M, Kose K, Kontas O, Dogam P, Kazez A 1995 Hypoxiainduced necrotizing enterocolitis in the immature rat: the role of lipid peroxidation and management by vitamin E. J Pediatr Surg 30:1416-1419

3. Goldman AS, Goldblum RM, Hanson LA 1990 Anti-inflammatory systems in human milk. Adv Exp Med Biol 262:69-76

4. Shoji H, Oguchi S, Shimizu T, Yamashiro Y 2003 Effect of human breast milk on urinary 8 -hydroxy-2'-deoxyguanosine excretion in infants. Pediatr Res 53:850-852

5. Shoji H, Oguchi S, Fujinaga S, Shinohara K, Kaneko K, Shimizu T, Yamashiro Y 2005 Effects of human milk and spermine on hydrogen peroxide-induced oxidative damage in IEC-6 cells. J Pediatr Gastroenterol Nutr 41:460-465
6. Pierce A, Colavizza D, Benaissa M, Maes P, Tartar A, Montreuil J, Spik G 1991 Molecular cloning and sequence analysis of bovine lactotransferrin. Eur J Biochem 196:177-184

7. Oguchi S, Walker WA, Sanderson IR 1995 Iron saturation alters the effect of lactoferrin on the proliferation and differentiation of human enterocytes (Caco-2 cells). Biol Neonate 67:330-339

8. van Vugt H, van Gool J, Ladiges NC, Boers W 1975 Lacoferrin in rabbit bile: its relation to iron metabolism. Q J Exp Physiol Cogn Med Sci 60:79-88

9. Reddy V, Bhaskaram C, Raghuramulu N, Jagadeesan V 1977 Antimicrobial factors in human milk. Acta Paediatr Scand 66:229-232

10. Legrand D, Elass E, Pierce A, Mazurier J 2004 Lactoferrin and host defence: an overview of its immuno-modulating and anti-inflammatory properties. Biometals $17: 225-229$

11. Lu L, Hangoc G, Oliff A, Chen LT, Shen RN, Broxmeyer HE 1987 Protective influence of lactoferrin on mice infected with the polycythemia-inducing strain of Friend virus complex. Cancer Res 47:4184-4188

12. Gutteridge JM, Paterson SK, Segal AW, Halliwell B 1981 Inhibition of lipid peroxidation by the iron-binding protein lactoferrin. Biochem J 199:259-261

13. Lonnerdal B, Forsum E, Hambraeus L 1976 A longitudinal study of the protein, nitrogen, and lactose contents of human milk from Swedish well-nourished mothers. Am J Clin Nutr 29:1127-1133

14. Hempel SL, Buettner GR, O'Malley YQ, Wessels DA, Flaherty DM 1999 Dihydrofluorescein diacetate is superior for detecting intracellular oxidants: comparison with $2^{\prime}, 7^{\prime}$-dichlorodihydrofluorescein diacetate, 5(and 6)-carboxy-2',7'dichlorodihydrofluorescein diacetate, and dihydrorhodamine 123. Free Radic Biol Med 27:146-159

15. Borenfreund E, Puerner JA 1985 Toxicity determined in vitro by morphological alterations and neutral red absorption. Toxicol Lett 24:119-124

16. Huang SW, Satué-Gracia MT, Frankel EN, German JB 1999 Effect of lactoferrin on oxidative stability of corn oil emulsions and liposomes. J Agric Food Chem 47:1356-1361

17. Britigan BE, Serody JS, Hayek MB, Charniga LM, Cohen MS 1991 Uptake of lactoferrin by mononuclear phagocytes inhibits their ability to form hydroxyl radical and protects them from membrane autoperoxidation. J Immunol 147:4271-4277

18. Kawakami H, Lonnerdal B 1991 Isolation and function of a receptor for human lactoferrin in human fetal intestinal brush-border membranes. Am J Physiol 261:G841-G846

19. Zhang L, Szeto KY, Wong WB, Loh TT, Sadler PJ, Sun H 2001 Interactions of bismuth with human lactoferrin and recognition of the $\mathrm{Bi}(\mathrm{III})$-lactoferrin complex by intestinal cells. Biochemistry 40:13281-13287

20. Suzuki YA, Shin K, Lonnerdal B 2001 Molecular cloning and functional expression of a human intestinal lactoferrin receptor. Biochemistry 40:15771-15779

21. Ashida K, Sasaki H, Suzuki YA, Lonnerdal B 2004 Cellular internalization of lactoferrin in intestinal epithelial cells. Biometals 17:311-315

22. LeBel CP, Ischiropoulos H, Bondy SC 1992 Evaluation of the probe 2',7' dichlorofluorescin as an indicator of reactive oxygen species formation and oxidative stress. Chem Res Toxicol 5:227-231

23. Kane DJ, Sarafian TA, Anton R, Hahn H, Gralla EB, Valentine JS, Ord T, Bredesen DE 1993 Related Bcl-2 inhibition of neural death: decreased generation of reactive oxygen species. Science 262:1274-1277

24. Hockenbery DM, Oltvai ZN, Yin XM, Milliman CL, Korsmeyer SJ 1993 Bcl-2 functions in an antioxidant pathway to prevent apoptosis. Cell 75:241-251

25. Britigan BE, Lewis TS, McCormick ML, Wilson ME 1998 Evidence for the existence of a surface receptor for ferriclactoferrin and ferrictransferrin associated with the plasma membrane of the protozoan parasite Leishmania donovani. Adv Exp Med Biol 443:135-140

26. Sun H, Li H, Sadler PJ 1999 Transferrin as a metal in mediator. Chem Rev 99:2817-2842

27. Qian SY, Buettner GR 1999 Iron and dioxygen chemistry is an important route to initiation of biological free radical oxidations: an electron paramagnetic resonance spin trapping study. Free Radic Biol Med 26:1447-1456

28. American Academy of Pediatrics, Committee on Nutrition 1999 Iron fortification of infant formulas. Pediatrics 104:119-123.

29. Brock JH, Arzabe F, Lampreave F, Pineiro A 1976 The effect of trypsin on bovine transferrin and lactoferrin. Biochim Biophys Acta 446:214-225

30. Davidson LA, Lonnerdal B 1987 Related persistence of human milk proteins in the breast-fed infant. Acta Paediatr Scand 76:733-740

31. Hernell O, Lonnerdal B 2002 Iron status of infants fed low-iron formula: no effect of added bovine lactoferrin or nucleotides. Am J Clin Nutr 76:858-864

32. Chierici R, Sawatzki G, Tamisari L, Volpato S, Vigi V 1992 Supplementation of an adapted formula with bovine lactoferrin. 2. Effects on serum iron, ferritin and zinc levels. Acta Paediatr 81:475-479

33. Davidson LA, Lonnerdal B 1988 Specific binding of lactoferrin to brush-border membrane: ontogeny and effect of glycan chain. Am J Physiol 254:G580-G585

34. Suzuki YA, Kelleher SL, Yalda D, Wu L, Huang J, Huang N, Lonnerdal B 2003 Expression, characterization, and biologic activity of recombinant human lactoferrin in rice. J Pediatr Gastroenterol Nutr 36:190-199 